\title{
LIPID PROFILE IN CIRRHOTIC PATIENTS AND ITS RELATION TO CLINICAL OUTCOME
}

\author{
Perfil lipídico de pacientes cirróticos e sua relação com o desfecho clínico
}

Laura BOEMEKE, Lilian BASSANI, Cláudio Augusto MARRONI, Catarina Bertaso Andreatta GOTTSCHALL

From the Universidade Federal de Ciências da Saúde de Porto Alegre e Irmandade Santa Casa de Misericórdia de Porto Alegre (Federal University of Health Sciences of Porto Alegre and Santa Casa de Porto Alegre), Porto Alegre, RS, Brazil.
HEADINGS - Liver cirrhosis. Outcome. Hepatitis C. Lipoproteins.
ABSTRACT- Background: Carriers of hepatitis C virus have lower levels of total cholesterol, high density lipoprotein-cholesterol, low density lipoprotein- cholesterol and triglycerides compared to uninfected patients. With the progression of liver disease, the values for cholesterol and its fractions reduce linearly, with reduction ratio of lipid profile and markers Child-Pugh and MELD. Aim -To determine the relationship between decrease dlipid profile with clinical outcome presented (liver transplantation or death pre-transplant). Methods: Was conducted a cross sectional analytical study of a follow-up study performed by reviewing medical records. Cirrhotic patients treated at theClinic of Gastroenterology from a large tertiary hospital with cirrhosis of viral etiology and/or alcohol were studied. The clinical characteristics (gender, age and etiology of cirrhosis) and lipid profile data from150 patients were collected in the year 2010.To analyze the occurrence of clinical outcomes (liver transplantation or death pre-transplant) patients were evaluated after four years. Results: The prevalent cause was hepatitis C virus (53,3\%), followed by alcohol (32\%) and hepatitis $C$ and alcohol $(14,6 \%)$. Males represented $62 \%$ of the sample and the average age was $63.1 \pm 9.11$ years. The prevalent lipid changes were hypocholesterolemia associated with hypotriglyceridemia $(36,6 \%)$ and isolated hypocholesterolemia $(34,6 \%)$. Analyzing groups of patients that showed abnormalities related to lipid profile, was identified a significant association between isolated hypocholesterolemia and clinical outcome-liver transplant $(p<0.025)$ and $18 \%$ probability of performing liver transplantation in this group of patients. There was no association between decreased lipid profile and death. Conclusion: Isolated hypocholesterolemia contributes to assess the progression of liver disease, because of the association between lowering cholesterol and its fractions and the clinical outcome - liver transplant.

\section{Correspondence: \\ Laura Boemeke \\ E-mail: laurabboemeke@gmail.com \\ Financial source: none \\ Conflicts of interest: none}

Received for publication: 14/10/2014 Accepted for publication: 20/01/2015

DESCRITORES - Cirrose hepática. Desfecho. Hepatite C. Lipoproteínas.
RESUMO - Racional: Portadores do vírus da hepatite $\mathrm{C}$ apresentam menores valores de colesterol total, lipoproteína de alta densidade, lipoproteína de baixa densidade e triglicerídeos, quando comparados aos pacientes não infectados. Com a progressão da hepatopatia, os valores de colesterol e suas frações reduzem linearmente, havendo relação entre redução do perfil lipídico e os marcadores Child-Pugh e MELD. Objetivo: Verificar a relação entre redução do perfil lipídico e o desfecho clínico apresentado (transplante hepático ou óbito pré-transplante). Métodos - Análise transversal de um estudo de acompanhamento, realizado através da revisão de prontuários médicos. Foram estudados pacientes cirróticos, acompanhados no Ambulatório de Gastroenterologia de um hospital terciário de grande porte com cirrose de causa viral e/ou alcoólica. As características clínicas (sexo, idade e etiologia da cirrose) e dados de perfil lipídico dos 150 pacientes estudados foram coletados no ano de 2010. Para análise da ocorrência dos desfechos clínicos, os pacientes foram avaliados após quatro anos. Resultados - A causa prevalente foi vírus da hepatite C (53,3\%), seguida de álcool (32\%) e vírus da hepatite C e álcool $(14,6 \%)$. O sexo masculino representou $62 \%$ da amostra e a média de idade foi de $63,1 \pm 9,11$ anos. As alterações lipídicas prevalentes foram hipocolesterolemia associada à hipotrigliceridemia $(36,6 \%)$ e hipocolesterolemia isolada (34,6\%). Analisando-se os grupos de pacientes que apresentaram alteração referente ao perfil lipídico, identificou-se associação significativa entre hipocolesterolemia isolada e o desfecho clínico - transplante hepático $(p<0,025)$, sendo $18 \%$ a probabilidade de realização de transplante hepático neste grupo de pacientes. Não houve associação entre redução do perfil lipídico e óbito. Conclusão: A hipocolesterolemia isolada contribui para avaliação da progressão da hepatopatia, devido à associação entre redução do colesterol e suas frações e o desfecho clínico-transplante hepático.

\section{INTRODUCTION}

T he liver plays central role in lipid homeostasis maintenance in the organism. The hepatitis C virus (HCV) is responsible for the chronic infection of 160 million people worldwide ${ }^{7}$ and for causing $27 \%$ of cases of cirrhosis ${ }^{4}$. The epidemiology of viral hepatitis in Latin America has changed quickly, so that the prevalence of HCV-infected individuals has increased. In Brazil, the virus affects around 1.5 million people, out of which $13 \%$ of cases are in Rio Grande do Sul ${ }^{17}$.

$\mathrm{HCV}$ infection is intimately associated with lipid alterations; the virus uses the host's lipid metabolism to sustain its vital $\mathrm{cycle}^{16}$. As a result, steatosis and hypocholesterolemia states are frequently observed among patients with chronic liver disease ${ }^{6}$.

Carriers of hepatitis C virus have lower levels of total cholesterol, high density 
lipoprotein-cholesterol, low density lipoprotein-cholesterol and triglycerides compared to uninfected patients. Values for cholesterol and its fractions reduce linearly with the progression of liver disease ${ }^{8}$. Studies ${ }^{1,19,12}$ suggest that the usage of lipid profile as prognostic indicator in patients with advanced liver disease due to the relation between cholesterol levels and its fractions reduction and the Child-Pugh score and the MELD (Model for End Stage Liver Disease).

The main purpose of this paper is to verify the relationship between decreased lipid profile with clinical outcome presented (liver transplantation or death pre-transplant) in a period of four years.

\section{METHODS}

This study has been approved by the Research Ethic Committee of the health institution and by the Research Ethic Committee of Universidade Federal de Ciências da Saúde de Porto Alegre, protocol \#621.408.

The paper consists of a cross sectional analytical study of a follow-up performed by reviewing medical records of the year 2010, when the lipid profile data from 153 cirrhotic adult patients was collected, regardless of their ethnic group or gender. Cirrhosis of viral etiology (HCV) and/or alcohol were studied. The diagnosis was proven through clinical, histological and image exams. The patients of the study were treated at the Clinic of Gastroenterology from a large tertiary hospital in the city of Porto Alegre, RS. Patients presenting other hepatic dysfunction (hepatocellular carcinoma, Wilson's disease), with autoimmune diseases (systemic lupus erythematous, rheumatoid arthritis), with antibodies against the human immunodeficiency virus (HIV), with renal insufficiency and other diseases that could interfere the lipid metabolism (primary dyslipidemia, cystic fibrosis) or that had undergone hepatic transplantation were excluded from this study.

From 153 patients analyzed in the year 2010, there has not been found information referring to clinical outcome (liver transplantation or death pre-transplant) of three patients, therefore those were excluded of this study. The patients were evaluated within four years, after definition of their lipid profile, carried in the year 2010, when information referring to clinic characteristics (gender, age and etiology of cirrhosis) and biochemical (total cholesterol, high density lipoprotein-cholesterol, low density lipoprotein-cholesterol and triglycerides) was collected from all patients in order to analyze the relationship between lipid alterations and clinical outcome after four years of study. The blood collections were made at the central laboratory of the referred hospital. Data referring to clinical outcome (liver transplantation or death pre-transplant) were collected between May and July, 2014.

The criteria used to define hypocholesterolemia were: TC $<100 \mathrm{mg} / \mathrm{dl}$ and/or HDL-cholesterol $<40 \mathrm{mg} / \mathrm{dl}$ and/or LDL-cholesterol $<70 \mathrm{mg} / \mathrm{dl}$ and/or VLDL $<16 \mathrm{mg} / \mathrm{dl}$ and for hypotriglyceridemia value of TG $<70 \mathrm{mg} / \mathrm{dl}$.

Data processing and statistical analysis were respectively carried through the creation of an Excel 2013 data bank and version 20.0 SPSS (Statistical Package for the Social Sciences) software. For descriptive analysis of quantitative variables mean and standard deviation were used. To evaluate the association between lipid profile and clinical outcome, the Pearson's chi-squared test was applied. Poisson regression with robust variance was calculated in order to identify the prevalence ratio of hypocholesterolemia and liver transplantation. The statistical significance adopted was $5 \%$.
RESULTS

The sample consisted of 150 patients. Hepatitis C virus was the prevalent cause (53.3\%), followed by alcohol (32\%) and HCV and alcohol (14.6\%). Males represented 62\% of the sample and the average age was $63.1 \pm 9.11$ years. Hypocholesterolemia associated with hypotriglyceridemia (36.6\%) were the prevalent lipid alterations, followed by isolated hypocholesterolemia (34.6\%).

TABLE 1 - Characteristics of the 150 analyzed patients

\begin{tabular}{|l|c|}
\hline Characteristics & Values $\mathbf{n}(\%)$ \\
\hline $\begin{array}{l}\text { Gender, } \mathrm{n}(\%) \\
\quad \text { Male }\end{array}$ & $93(62)$ \\
\hline $\begin{array}{l}\text { Female } \\
\text { Age, years }\end{array}$ & $57(38)$ \\
\hline Etiology of cirrhosis & $63.1 \pm 9.11$ \\
\hline HCV & $80(53.3)$ \\
\hline \multicolumn{1}{|c|}{ Alcohol } & $48(32)$ \\
\hline HCV + alcohol & $22(14.6)$ \\
\hline Lipid Profile & \\
\hline Hypocholesterolemia & $52(34.6)$ \\
\hline Hypotriglyceridemia & $01(0.66)$ \\
\hline Hypocholesterolemia e hypotriglyceridemia & $55(36.6)$ \\
\hline No modification & $42(28)$ \\
\hline
\end{tabular}

$\mathrm{HCV}=$ hepatitis $\mathrm{C}$ Virus

Among 150 evaluated individuals, 39 underwent hepatic transplantation. The percentage of transplantations was larger in the group of patients that developed hypocholesterolemia associated with hypotriglyceridemia (32.7\%), followed by the group that developed isolated hypocholesterolemia (30.7\%). There was significant association between isolated hypocholesterolemia and hepatic transplantation $(p=0.025)$ (Table 2). Poisson regression with robust variance was calculated in order to identify the prevalence ratio of isolated hypocholesterolemia and liver transplantation. Through the test, it was identified that the probability of liver transplantation in patients that developed isolated hypocholesterolemia was $18 \%$ compared to the other groups of patients (isolated hypotriglyceridemia, hypocholesterolemia associated with hypotriglyceridemia and patients without lipid profile alteration).

In the course of the study, 25 patients died. The group of patients that presented hypocholesterolemia associated with hypotriglyceridemia represented the group with the majority of deaths (20\%), followed by the group that presented isolated hypocholesterolemia (15.3\%). There was no association between lipid profile reduction and clinical outcome - death.

TABLE 2 - Lipid profile associated with clinical outcome

\begin{tabular}{|c|c|c|c|c|}
\hline Lipid Profile & OLT- $\mathbf{n}(\%)$ & $\mathrm{P}$ & Death $-\mathrm{n}(\%)$ & $\mathrm{p}$ \\
\hline Hypocholesterolemia & $16(30.7)$ & 0.025 & $08(15.3)$ & 1,000 \\
\hline $\begin{array}{c}\text { Hypotriglyceridemia } \\
\text { Hypocholesterolemia }\end{array}$ & $01(100)$ & 0.226 & $0(0)$ & 1,000 \\
$\begin{array}{c}\text { and Hypotriglyceridemia } \\
\text { No modification }\end{array}$ & $18(32.7)$ & 0.216 & $11(20)$ & 0.544 \\
\hline
\end{tabular}

OLT=orthotopic liver transplantation

It was not possible to identify the cause of death in $68 \%$ of patients. Shocks of unknown cause were the main reason of death described in pre-transplant, corresponding to $12 \%$ of patients, followed by other causes, including: multiple organ failure, superior digestive hemorrhage, hepatopulmonary syndrome, portosystemic encephalopathy and hemorrhagic stroke (Table 3). 
TABLE 3 - Causes of death

\begin{tabular}{|c|c|}
\hline Cause of death & Death - n (\%) \\
\hline Unknown & $17(68)$ \\
\hline Shock of unknown cause & $03(12)$ \\
\hline Others & $05(20)$ \\
\hline
\end{tabular}

\section{DISCUSSION}

In the present study, it was investigated the relationship between lipid profile reduction in hepatitis C virus (HCV) and/or alcohol cirrhotic patients and the clinical outcome presented (liver transplantation or death pre-transplant). The results indicated that among the evaluated patients, the prevalent lipid alteration was hypocholesterolemia associated with hypotriglyceridemia.

Analyzing the lipid profile alterations, it was observed significant association between cholesterol reduction and its fractions and clinical outcome - liver transplantation. The probability of performing hepatic transplantation in the group that developed isolated hypocholesterolemia was 18\% compared to other groups (hypocholesterolemia associated with hypotriglyceridemia, isolated hypotriglyceridemia and without lipid alteration).

Liver is the central organ of lipid metabolism in the organism, vital for synthetizing blood lipids and lipoproteins. Hepatitis $C$ virus has the hepatocyte as target-cell, and its entrance in the cell occurs through apolipo protein $\mathrm{E}$ recognition by the receptor, being LDL-cholesterol the probable mediator. After entering the hepatocyte and replicating its genetic material, the virus is excreted by the liver and transported in the organism associated with VLDL cholesterol, through the formation of a complex designated as lipo-viro-particle, which allows the virus to escape the detection of the immune system and keep the infection ${ }^{6}$. All phases in HCV's lifecycle are intimately associated with intracellular machinery involved in lipid metabolism, suggesting that lipid metabolism plays an important role in the pathogenesis of the infection ${ }^{18}$.

Beyond hepatic level alterations, the virus presents extra-hepatic manifestations, such as metabolic disorders that commonly result in hepatic steatosis and hypocholesterolemia development, characterized by enhancing the triglyceride level and reducing cholesterol and its fractions, respectively ${ }^{20,6}$. The present study identified that, although the percentage of liver transplantation was slightly higher in the group that developed hypocholesterolemia associated with hypotriglyceridemia, there has been significant association only between isolated hypocholesterolemia and clinical outcome-liver transplantation. The hypothesis for the fact that liver transplantation had been significantly associated with isolated hypocholesterolemia is that carriers of hepatitis $C$ virus often present reduction of cholesterol and its fractions and increase of triglycerides in the liver, due to HCV infection mechanisms.

Although host facts, including gender, age, diseases and/or nutritional state, can influence lipid serum level, a study developed by Miyazaki and collaborators ${ }^{15}$, identified that total cholesterol, HDL-cholesterol, LDL-cholesterol and triglycerides serum levels were significantly lower in carriers of hepatitis C virus, compared to uninfected patients, independently to gender, age, body mass index or aminotransferase serum levels. The result found indicates that HCV is associated - independently - with alterations in the lipid metabolism.

Themechanismby which the virusleads to hypocholesterolemia development has not been completely elucidated yet. The main hypothesis is that it acts reducing microsomal triglycerides transfer protein (MTTP) activity and, this way, altering the host's lipid production and secretion. Reduction of MTTP activity due to HCV provides the first evidence that there is direct effect of the virus on production and secretion of VLDL ${ }^{3}$. Secretions of VLDL unbalanced by hepatocytes have been associated with hypocholesterolemia, and this metabolic disorder is generally found associated with the lowest values of triglycerides ${ }^{10}$.

In chronic hepatic disease, not only triglycerides and blood cholesterol reduction has been identified, but also the other plasmatic lipoproteins, as LDL-cholesterol. Part of the cholesterol present in VLDL, that remains in the lipoprotein after triglycerides distribution, is then on called remnant cholesterol, which will be distributed to the tissues as LDL-cholesterol. Thus, reduction of VLDL production and secretion leads to LDL-cholesterol reduction, as highlighted in studies that identify low values of TC and LDL-Cholesterol in carriers of hepatitis C virus compared to uninfected patients ${ }^{5,11,14}$. HDL-cholesterol reduction has also been identified, since around $90 \%$ of HDL is synthetized in the liver ${ }^{13}$ and in cirrhotic patients the liver damage conducts to the reduction of the organ functions. A study developed by Alavian and collaborators ${ }^{2}$ identified that $72 \%$ of the sample of cirrhotic carriers of hepatitis $C$ virus presented low value of HDL-cholesterol. Data found in the present study corroborates studies previously mentioned $5,11,14,13,2$, since gathering data referring to isolated hypocholesterolemia and hypocholesterolemia associated with hypotriglyceridemia, it is identified that $71.2 \%$ of the studied sample presented lipid profile reduction.

Alteration in lipid metabolism of carriers of hepatitis $C$ virus has been related to the severity of hepatic disease, due to positive association between lipid parameters reduction and advanced fibrosis ${ }^{4}$. Cases of higher severity are most recommended to liver transplantation. The present study identified that $30.7 \%$ of patients that developed isolated hypocholesterolemia pre-transplant underwent liver transplantation $(p=0.025)$, emphasizing that the reduction of cholesterol and its fractions is related to the severity of the disease and the clinical outcome.

A study developed by Habib and collaborators ${ }^{9}$ identified that patients that present lower values of $\mathrm{HDL}$-cholesterol are more inclined to undergo liver transplantation in a year. Probabilities of death or liver transplantation in a year exceeded $60 \%$ in patients with $\mathrm{HDL}$-cholesterol levels inferior to $30 \mathrm{mg} /$ dl. Besides, the study identified that HDL-cholesterol levels inferior to $30 \mathrm{mg} / \mathrm{dl}$ were associated with the increase of 3.4 times incases of death, suggesting that HDL-cholesterol works as a liver functions test and prognostic indicator to viral and/or alcoholic cirrhotic patients.

A study by Janicko and collaborators ${ }^{12}$ identified relation between lipid profile and clinical outcome of alcoholic cirrhotic patients. The study evaluated 191 patients in which death was the main clinical outcome. There was significant difference in total serum cholesterol levels between patients who died at the end of the study and those who survived. Although clinical outcome - death - has not been associated with lipid profile reduction in the present study, it must be considered that the patients evaluated in the mentioned study ${ }^{12}$ were alcoholic cirrhotic patients, what differs from the sample in the present study, which consisted of viral cirrhotic patients mainly.

In this study, there was no association between lipid profile reduction and death. The hypothesis is that this relationship has not been observed due to the fact that most of evaluated patients had undergone transplantation, indicating that profile reduction still presents association with the severity of hepatic disease and the presented clinical outcome.

This study presents some limitations. Even though it was mentioned the relationship between hypocholesterolemia and hepatic steatosis development in carriers of hepatitis 
$C$ virus, the sample studied was not submitted to exams of hepatic steatosis confirmation diagnosis. Besides, data was collected though revision of medical records, what also made the collection of prognostic criteria data impossible (Child Pugh score and MELD).

\section{CONCLUSION}

The study of lipid profile in alcoholic and viral cirrhotic patients (carriers of hepatitis C virus) aids to identify the severity of liver damage. Isolated hypocholesterolemia contributes to evaluation of hepatic progression, due to association between the reduction of cholesterol and its fractions and clinical outcome - liver transplantation.

\section{REFERENCES}

1. Abbasi A, Bhutto AR, Butt N, Lal K, MunirSM. Serumcholesterol: could it be a sixthparameterofChild-Pughscoring system in cirrhoticsdueto viral hepatitis?.J Coll PhysiciansSurg Pak. 2012;(8):484-7

2. Alavian SM, Miri SM, Tabatabaei SV, Keshvari M, Behnava B, Elizee PK, et al. Lipid profiles and hepatitis C viral markers in HCV-infected thalassemic patients. Gut Liver. 2011;5:348-55.

3. André P, Perlemuter G, Budkowska A, Bréchot C, Lotteau V. Hepatitis $C$ virus particles and lipoprotein metabolism. Semin. Liver Dis. 2005;25:93-104.

4. Bassendine MF, Sheridan DA, Bridge SH, Felmlee DJ, Neely RDG. Lipids and HCV. Semin. Immunopathol. 2013:35:87-100.

5. Corey KE, Kane E, Munroe C, Barlow LL, Zheng H, Chung RT. Hepatitis Cvirus infection and its clearance alter circulating lipids: Implications for long-term follow-up. Hepatology. 2009;50:1030-7.

6. Felmlee DJ, Hafirassou ML, Lefevre M, Baumert TF, Schuster C. Hepatitis $C$ virus, cholesterol and lipoproteins- impact for the viral life cycle and pathogenesis of liver disease. Viruses. 2013;5:1292-324.

7. Fierro NA, Aldaco KG, Valadez RT, Lopez EM, Roman S, Panduro A. Immunologic, metabolicandgeneticfactorsinhepatitis C virusinfection. World J Gastroenterol. 2014; 20(13): 3443-3456
8. Ghadir MR, Riahin AA, Havaspour A, Nooranipour M, Habibinejad AA. The relationship between lipid profile and severity of liver damage in cirrhotic patients. Hepat. Mon. 2010;10:285-8.

9. Habib A, Mihas AA, Abou-Assi SG, Williams LM, Gavis E, Pandak $W M$, et al. High-density lipoprotein cholesterol as an indicator of liver function and prognosis in noncholestatic cirrhotics. Clin. Gastroenterol. Hepatol. 2005;3(3):286-91.

10. Honda A, Matsuzaki Y. Cholesterol and chronic hepatitis $C$ virus infection. Hepatol. Res. 2011:41:697-710.

11. Hsu CS, Liu CJ, Liu CH, Chen CL, Lai MY, Chen PJ, et al. Metabolic profiles in patients with chronic hepatitis $\mathrm{C}$ : a case-control study. Hepatol. Int. 2008;2:250-7.

12. Janicko $M$, Veselíny $E$, Lesko $D$, Jarcuska P. Serum cholesterol is a significant and independent mortality predictor in liver cirrhosis patients. Ann. Hepatol. 2013;12:581-7.

13. Jiang M, Liu F, Xiong WJ, Zhong L, Xu W, Xu F, et al. Combined MELD and blood lipid level in evaluating the prognosis of decompensated cirrhosis. World J. Gastroenterol. 2010;16:1397-401.

14. Lao XQ, Thompson A, McHutchison JG, McCarthy JJ. Sex and age differences in lipid response to chronic infection with the hepatitis $C$ virus in the United States National Health and Nutrition Examination Surveys. J. Viral Hepat. 2011; 18(8):571-9.

15. Miyazaki T, Honda A, Ikegami T, Saitoh Y, Hirayama T, Hara T, et al. Hepatitis $C$ virus infection causes hypolipidemia regardless of hepatic damage or nutritional state: An epidemiological survey of a large Japanese cohort. Hepatol. Res. 2011;41:530-41

16. Popescu CI, Dubuisson J. Role of lipid metabolism in hepatitis C virus assembly and entry. Biol. Cell. 2010;102:63-74.

17. Portal Brasil, Ministério da Saúde [Homepage na Internet]. Pacientes terão acesso a dois novos medicamentos contra a hepatite $C$ no SUS [Atualizada em 2012 Jul 25; acesso em 2013 Dez 9]. Disponível em: http://www.brasil.gov.br/saude

18. Schaefer EAK, Chung RT. HCV and hostlipids: An intimate connection. Semin. Liver Dis. 2013;33:358-68.

19. Subhan F, Khan I, Arif R, Khan A, Khan A. Serumlipid profile as anindicatoroftheseverityofliverdamage in cirrhoticpatients. Rawal Medical Journal. 2012; 37(4): 387-389

20. Vere CC, Streba CT, Streba L, Rogoveanu I. Lipid serum profile in patients with viral liver cirrhosis. Med. Princ. Pract. 2012;21:566-8. 